\title{
SCIDiC
}

\author{
International Journal of Dentistry and Oral Science (IJDOS) \\ ISSN: 2377-8075
}

\section{Prevalence Of Oral Mucocele In Patients Attending Private Dental Hospital - A Retrospective Study}

Research Article

Amanthi Ganapathi ${ }^{1}$, Jagadish Vijayakumar ${ }^{2}$, M.Jeevitha ${ }^{3}$

${ }^{1}$ Saveetha Dental College and Hospitals, Saveetha Institute of Medical and Technical Sciences, Chennai - 600 077, TN, India.

${ }^{2}$ Senior Lecturer, Department of Oral \& Maxillofacial Surgery, Saveetha Dental College, Saveetha Institute of Medical and Technical Sciences, Saveetha University, 162, Poonamallee High Road, Chennai - 600077, Tamil Nadu, India.

${ }^{3}$ Senior Lecturer, Department of Periodontics, Saveetha Dental College, Saveetha Institute of Medical and Technical Sciences, Saveetha University, 162 , Poonamallee High Road, Chennai - 600077, Tamil Nadu, India.

\section{Abstract}

Oral mucocele is the most common benign minor (accessory) salivary gland lesion,caused due to mechanical trauma to the excretory duct of the gale.clinically they are characterized by single or multiple, soft fluctuant nodule, ranging from the normal color of the mucosa to deep blue. It affects all age group and is equally present in both sexeswith the higher incidences in second decade of the life.They are classified as extravasation or retention types. The determine the distribution of oral mucocele in patients of Saveetha dental college \& hospitals, Chennai.Further to identify the sex, duration and age predilection. A hospital based retrospective study was carried out from June 2018 to March 2020 at Saveetha dental college \& hospitals, Chennai. A total of 34 biopsy reports were studied. Distribution and prevalence of oral mucocele were analysed using SPSS software. In our study a total of 34 patients out of which male population showed more prevalence of $64 \%$ than the female population.It is found in people aged above 40 years old to $50 \%$ and the duration was less than a month $32.4 \%$. Our study shows prevalence of $50 \%$ of mucocele in male population above 40 years.

Keywords: Oral Mucocele; Ranula; Salivary Gland.

\section{Introduction}

Mucoceles are defined as mucus filled cavities which can appear in the oral cavity,appendix gallbladder,paranasal sinus, and lacrimal sac $[1,2]$. The term "mucocele" is derived from a Latin word mucus and "cocele"means cavity [3]. It is the 17th most common salivary gland lesion seen in the oral cavity [4]. Mucocele is usually painless and have a tendency to relapse [5, 6]. Accumulation of liquid or mucous materials due to alteration of minor salivary gland which causes mucocele with a limited swelling [7, 8]. They are classified as extravasation or retention cyst $[8,9]$. Patients are often anxious on visiting a dentist and receiving treatment so treatment is not taken on time which leads to further complication [10]. General dentist must have awareness regarding the signs and symptoms so,that it will be easy for them to educate the patient [10]. Patients with poor oral hygiene and immunocompromised must be taken care and their specific treatment protocol [11].
The two main etiological factor are trauma and obstruction of salivary gland.The main reason will be physical trauma which causes silage of salivary secrecy ion into surrounding submucosal tissue,Due to stagnate mucous inflammation may become obvious $[12,13]$. Habit of lip biting and tongue thrusting are also one of the aggravated factor $[13,14]$. Clinically there are two types ,extravasation and retention types extravasation and retention type and Extravasation this due to the leaks of fluid from the damaged salivary gland and acini into surrounding soft tissue,mostly seen commonly in major salivary gland ducts $[12,13]$. Retention $\mathrm{Mu}-$ cocele appears dude to a decreases or absence of glandular secrecy ion produced by blockage of salivary gland ducts [12]. When located in the floor of the mouth these lesions are called ranulas because the inflammation resembles the cheek of frog $[15,16]$.

The incidence of mucocele of generally high 2.5 lesion per 1000

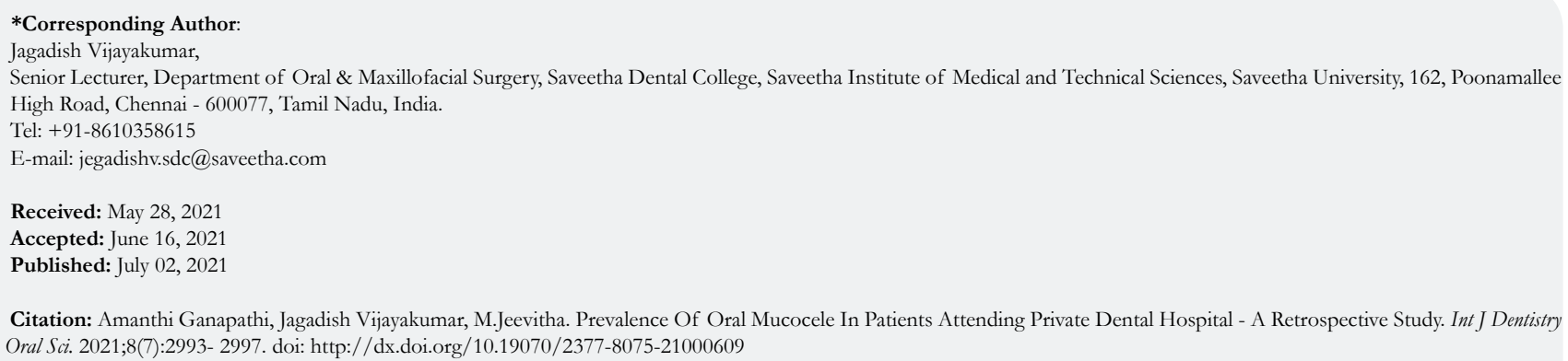

Citation: Amanthi Ganapathi, Jagadish Vijayakumar, M.Jeevitha. Prevalence Of Oral Mucocele In Patients Attending Private Dental Hospital - A Retrospective Study. Int J Dentistry Oral Sci. 2021;8(7):2993- 2997. doi: http://dx.doi.org/10.19070/2377-8075-21000609

Copyright: Jagadish Vijayakumar ${ }^{\circ} 2021$. This is an open-access article distributed under the terms of the Creative Commons Attribution License, which permits unrestricted use, distribution and reproduction in any medium, provided the original author and source are credited. 
patients, frequently in the second decade of life $[3,17,18]$ no clinical difference between extravasation and retention Mucocele. Mucocele present a bluish, soft and transparent cystic swelling which frequently resolves spontaneously. The blue color is caused by vascular congestion and tissue cyanosis of tissue above and the accumulation of fluid below. Coloration can also vacancy depending on the size of the lesion, proximity to the surface and upper tissue elasticity $[1,18,19]$. Mucocele found in the minor salivary gland are rarely larger than $1.5 \mathrm{~cm}$ in diameter and are always superficial.Mucocele found in deeper areas are usually larger. Mucocele can cause a convex swelling depending on the size and location ,as well as difficulties in speaking or chewing [1]. The lower lip is the most frequent site for a Mucocele as Otis the most probable place for a trauma,especially at premolar level. There is a prevalence 2.5 lesion per 1000 population in America $.0 .11 \%$ in Sweden and $0.08 \%$ in Brazil [20]. In India the highly prevalent age group of $15-24$ years p,were seen at $51,72 \%$ males and $48.28 \%$ of females with a ratio of 1.07:1. Previously our team has a rich experience in working on various research projects across multiple disciplines [21-35]. The aim of this study is to find the prevalence rate of oral mucocele.

\section{Materials And Methods}

\section{Study design and study setting}

The study was retrospective data analysis. The data was collected from the hospital based patient case records of 86000 patients, during June 2019-March 2020

\section{Participants}

All patients with oral mucocele were included in the study.All the diagnosis parameters were satisfied

\section{Inclusion criteria}

1. Patients with oral mucocele

\section{Exclusion criteria}

1. Syndrome patients

2. Physical disabilities

3. HIV-AIDS

4. Mentally challenged patients

\section{Study size}

The sample size was 34 patients

\section{Ethical approval}

The ethical approval for the research (SDC/SIHEC/2020/DIASDATA/0619-0320) was issued by the ethical committee of Saveetha Dental college, Saveetha Institute of medical and Technical science, Saveetha University, Chennai.

\section{Data Analysis}

The data was collected from patient reports in hospitals, The obtained data was entered in microsoft excel 2012. Then export- ed to statistical package for social science for windows (version 20.0.SPSS Inc., Chicago III,USA)and all subjected to statistical analysis.Chi square test was employed with a level of significance set at $\mathrm{P} 0.05$.

\section{Results And Discussion}

In our study there are total of 34 patient in which .Female patients showed $32.4 \%$.patients showed $67 \%$ (figure 1 ).So,high prevalence is seen among male population when compared to females.Distribution of age of the patients affected with mucocele is depicted in figure 2.Patients aged between less than 10-20 years old accounts for $11.7 \%$,patients aged between $21-30$ years old accounts for $20.5 \%$,patients aged between $31-40$ years old accounts for $17.6 \%$,patients aged between 40 years old and above accounts for $50 \%$.Figure 3-Duration Of the oral Mucocele. $>1$ month was $32.4 \%,>$ 6months $-23.5 \%, 1$ year and above was $26.5 \%$,unknown $-17.6 \%$.So, people with a duration of less than a month were found to be more. Figure 4 shows the association of age and mucocele, less than $10-20$ years showed $11 \%$ of prevalence, 21 30 years old patients showed 20\%, 31-40 years old showed $17 \%$ and 49 and above patients showed 50\%.So,high prevalence was seen among 40 and above age groups when compared to others. In our present study by comparing the duration and age of the patient the obtained $\mathrm{P}$ value is 0.104 which is less than 0.05 . Hence statically not significant. (Pearson Chi-Square correlation).Figure 5: By comparing the association between duration of mucocele and gender of the patient, results show that in male patients the duration of less than one month, one year and more than a year is more when compared to females. In females less than six months was found to be more when compared to male, however there is no significant difference between both the groups. The obtained $P$ value is 0.208 which is less than 0.05 . Hence not statically significant (Pearson Chi-Square correlation).

Mucocele is a clinical term used to describe a swelling caused by pooling of saliva from a severed or obstructed minor salivary gland duct [8]. The self limiting Mucocele containing yet of salivary salivary gland commonly occurring in the oral cavity with relatively rapid onset and with fluctuating size [21]. The decrease in size may be due to rupture of lesion and subsequent mucin accumulation or re-absorption of saliva deposits may causes the lesion to reform [36]. Oral mucoceles can be single or multiple often rupturing and leaving slightly painful ersonion that usually healed within few days [15]. The duration of the lesion is not constant from a few days to 3 years. The clinical presentation may vary depending on the depth of the lesion. The lesion are located under the mucosa membrane (superficial Mucocele) or in upper submucosa (clamical Mucocele) [20]. Sometimes patients who undergo trauma during road traffic accidents causes damage to the soft tissues mucosa of the lip and henceforth rupuring ducts of salivary gland which lead to oral mucocele $[35,37-40]$.

In our study oral mucocele has affected mostly the 4th and 5th decade of life.Where as there are few studies which support by saying that there is a high incidence is the second decade of life. Teenger and children are most commonly affected by menta et al [41] yamosoba et al [15] and Oliveira et al [42]. reported that more than $65 \%$ of their patients with Mucocele less the 20 years of age. However, this may be asymptomatic in nature may delay the patient in seeking treatment. In our present study age and 
Figure 1: Distribution of gender. $\mathrm{X}$ axis denotes the gender of the patient and $\mathrm{Y}$-axis denotes total number of patients. Male (67.65\%) population was more when compared to the female population $(32.35 \%)$.

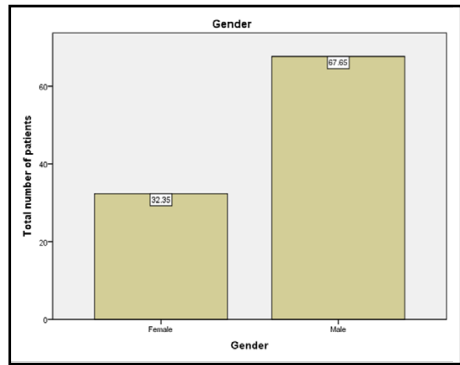

Figure 2: Association of age and mucocele. $\mathrm{X}$ axis showing the age of the patient and $\mathrm{Y}$ axis total number of patients. Mucocele was seen in $50 \%$ of patients above the age of 40 years.

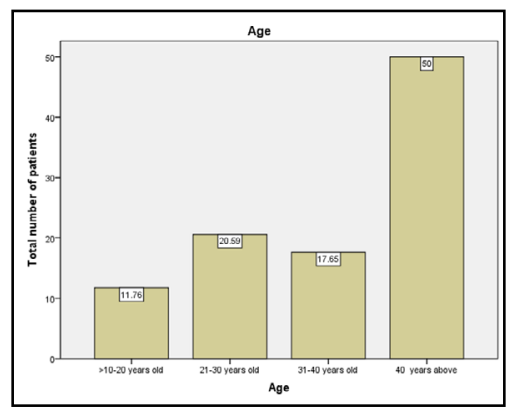

Figure 3: Bar graph represents duration of mucocele and total number of patients. $X$ axis showing the duration of mucocele and $\mathrm{Y}$ axis denotes total number of patients. The mucocele with more than one month of duration is more in our study population.

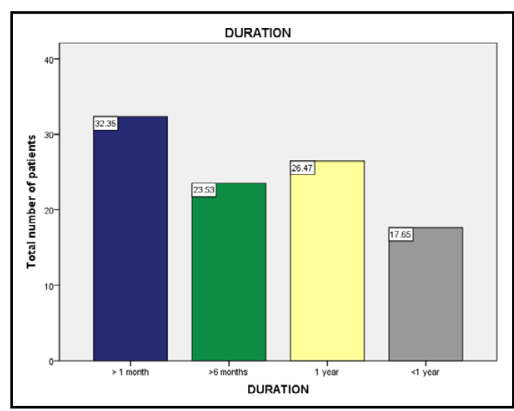

Figure 4: Bar graph represents association of age and duration of mucocele.X axis denotes the age of the patient.Y axis denotes the total number of patients affected with mucocele. By comparing the duration and age of the patient the obtained $P$ value is 0.104 which is less than $\mathbf{0 . 0 5}$. Hence not statically significant (Pearson Chi-Square correlation). From this graph it is evident that patients with 40 years and above had longer duration (17.65\%) of mucocele when compared to other age groups.

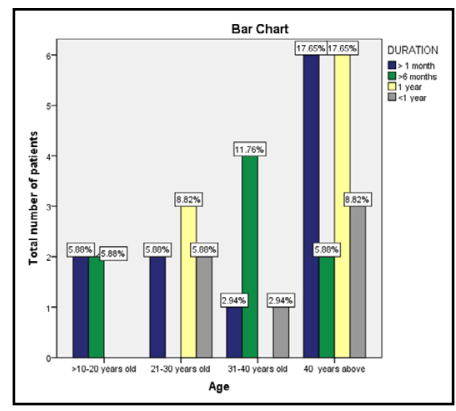

duration of mucocele was compared and it shows that patients above 40 years had mucocele duration of more than one month and less than one year. This shows the negligence by the higher age population in treating mucocele.

Our present study shows that male population with $67 \%$ higher prevalence than the female population.This is in regard with the studies of Yamaoba et al [15] Menta et al [41].studies of oliveira et al [42] with ratio of 1.071:1.Oral mucocele rare- ly causes significant problems.Discomfort interference with speech,mastication,swelling and external swelling may occur depending on the size and location [36].Oral mucocele is differentiated from lipoma, oral hemangioma, oral lymphangioma, benign or malignant salivary gland neoplasm, gingival systemic of adults, soft tissue abscess, cysticercosis. Mucocele may be confused with cicatricial pemphigoid,bullous lichen Planus etc [43].

The treatment shall be complete excision, marsupialization, dis- 
Figure 5: Bar graph represents association of gender and duration of mucocele.X axis denotes the gender of the patient.Y axis denotes the total number of patients affected with mucocele. By comparing the duration and gender of the patient the obtained $P$ value is $\mathbf{0 . 2 0 8}$ which is less than $\mathbf{0 . 0 5}$. Hence not statically significant (Pearson Chi-Square correlation). It is evident that in male patients the duration of mucocele of less than one month, one year and more than a year is more when compared to females. There is no significant difference between both the groups.

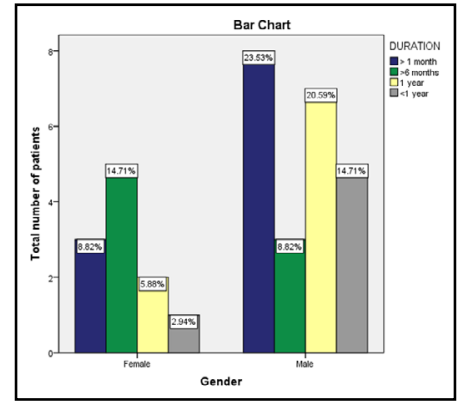

section, cryosurgery, $\mathrm{CO}_{2}$ laser, Intralesional injection of sclerosing agent Ok432 or steroid injection [15]. Post surgery antibiotics and mouth wash are administered to the patients to prevent further infection in the surgical site [11, 44-49]. Our institution is passionate about high quality evidence based research and has excelled in various fields [50-60].

\section{Conclusion}

From this study it is evident that the prevalence of oral Mucocele is more common among male population when compared to female and mostly seen among the 4th and 5th decade of life. This study helps in understanding the prevalence of mucocele in a limited population. Further studies are required in a larger population to assess its risk factors which will aid in proper diagnosis and treatment planning.

\section{Author's Contribution}

Author1(Amanthi Ganapathi) Carried out the retrospective study by collecting the data and drafting the manuscript after performing the necessary statistical analysis. Author 2 (Dr. Jagadis. V) aided in the conception of the topic,participated in the study design,statistical analysis and supervised the preparation of the manuscript and helped in study design and has coordinated in developing the manuscript. All the authors have equally contributed in developing this manuscript.

\section{Acknowledgement}

The authors of the study thank everyone who enabled us to carry out this study.

\section{References}

[1]. Copeland LB, Krall EA, Brown LJ, Garcia RI, Streckfus CF. Predictors 1. Baurmash HD. Mucoceles and ranulas. J Oral Maxillofac Surg. 2003 Mar 1;61(3):369-78.

[2]. Ozturk K, Yaman H, Arbag H, Koroglu D, Toy H. Submandibular gland mucocele: report of two cases. Oral Surg Oral Med Oral Pathol Oral Radiol Endod. 2005 Dec 1;100(6):732-5.

[3]. Yagüe-García J, España-Tost AJ, Berini-Aytés L, Gay-Escoda C. Treatment of oral mucocele-scalpel versus CO2 laser. Med Oral Patol Oral Cir Bucal. 2009 Sep 1;14(9):e469-74.Pubmed PMID: 19415059.

[4]. FLAITZ C, HICKS J. Nodular Fasciitis Involving the Head and Neck Region with Molecular Confirmation. Oral Surg Oral Med Oral Pathol Oral Radiol. 2015 Sep 1;120(3):e160.
[5]. Eveson JW. Superficial mucoceles: pitfall in clinical and microscopic diagnosis. Oral Surg Oral Med Oral Pathol. 1988 Sep;66(3):318-22.Pubmed PMID: 3174068.

[6]. Bermejo A, Aguirre JM, Lopez P, Saez MR. Superficial mucocele: report of 4 cases. Oral Surg Oral Med Oral Pathol Oral Radiol Endod. 1999 Oct $1 ; 88(4): 469-72$.

[7]. JV BS, FJ SD, Masanet M. Clinico-pathological study of oral mucoceles. Avances en odontoestomatologia. 1990 Sep 1;6(7):389-91.

[8]. Sugerman PB, Savage NW, Young WG. Mucocele of the anterior lingual salivary glands (glands of Blandin and Nuhn): report of 5 cases. Oral Surg Oral Med Oral Pathol Oral Radiol Endod. 2000 Oct;90(4):478-82.Pubmed PMID: 11027386.

[9]. Ata-Ali J, Carrillo C, Bonet C, Balaguer J, Peñarrocha M, Peńarrocha M. Oral mucocele: review of the literature. J Clin Exp Dent. 2010 Feb;2(1):e18-21.

[10]. Patturaja K, Pradeep D. Awareness of Basic Dental Procedure among General Population. Res J Pharm Technol. 2016 Sep 1;9(9):1349.

[11]. Kumar S, Rahman RE. Knowledge, awareness, and practices regarding biomedical waste management among undergraduate dental students. Asian J. Pharm. Clin. Res. 2017;10(8):341

[12]. Bonet FB, Homs EV, Tornil AM, Lagunas JG. Mucocele de la glandula submaxilar: a propósito de un caso Submaxillary gland mucocele: presentation of a case. Med Oral Patol Oral Cir Bucal. 2005;10:180-4.

[13]. Prasanna Kumar Rao SR, Laxmikanth C PS. Oral Mucocele-A Mini Review. Dentistry. 2013; 3(1):1-3.

[14]. Gupta B, Gupta M, Anegundi R, Sudha P. Mucocele: Two Case Reports . Vol. 1, J Oral Health Community Dent. 2007;1:56-8.

[15]. Yamasoba T, Tayama N, Syoji M, Fukuta M. Clinicostatistical study of lower lip mucoceles. Head Neck. 1990 Jul-Aug;12(4):316-20.Pubmed PMID: 2193904.

[16]. Packiri S, Gurunathan D, Selvarasu K. Management of paediatric oral ranula: a systematic review. J Clin Diagn Res. 2017 Sep;11(9):ZE06-9.

[17]. Guimarães MS, Hebling J, Filho VA, Santos LL, Vita TM, Costa CA. Extravasation mucocele involving the ventral surface of the tongue (glands of Blandin-Nuhn). Int. J. Paediatr. Dent. 2006 Nov;16(6):435-9.

[18]. Bentley JM, Barankin B, Guenther LC. A review of common pediatric lip lesions: herpes simplex/recurrent herpes labialis, impetigo, mucoceles, and hemangiomas. Clin Pediatr (Phila). 2003 Jul-Aug;42(6):475-82.Pubmed PMID: 12921448.

[19]. Tran TA, Parlette HL 3rd. Surgical pearl: removal of a large labial mucocele. J Am Acad Dermatol. 1999 May;40(5 Pt 1):760-2.Pubmed PMID: 10321607.

[20]. Rashid AK, Anwar N, Azizah AM, Narayan KA. Cases of mucocele treated in the Dental Department of Penang Hospital. Arch. Orofac. Sci. 2008;3(1):710.

[21]. Hafeez N. Accessory foramen in the middle cranial fossa. Res J Pharm Technol . 2016 Nov 1;9(11):1880.

[22]. Krishnan RP, Ramani P, Sherlin HJ, Sukumaran G, Ramasubramanian A, Jayaraj G, et al. Surgical Specimen Handover from Operation Theater to Laboratory: A Survey. Ann Maxillofac Surg. 2018 Jul-Dec;8(2):234-238. Pubmed PMID: 30693238.

[23]. Somasundaram S, Ravi K, Rajapandian K, Gurunathan D. Fluoride Content of Bottled Drinking Water in Chennai, Tamilnadu. J Clin Diagn Res. 2015 Oct;9(10):ZC32-4.Pubmed PMID: 26557612.

[24]. Felicita AS. Orthodontic extrusion of Ellis Class VIII fracture of maxillary lateral incisor - The sling shot method. Saudi Dent J. 2018 Jul;30(3):265269.Pubmed PMID: 29942113.

[25]. Kumar S, Rahman RE. Knowledge, awareness, and practices regarding bio- 
medical waste management among undergraduate dental students. Asian J. Pharm. Clin. Res. 2017;10(8):341.

[26]. Gurunathan D, Shanmugaavel AK. Dental neglect among children in Chennai. J Indian Soc Pedod Prev Dent. 2016 Oct 1;34(4):364.

[27]. Sneha S. Knowledge and awareness regarding antibiotic prophylaxis for infective endocarditis among undergraduate dental students. Asian J. Pharm. Clin. Res. 2016 Oct 1:154-9.

[28]. Dhinesh B, Lalvani JI, Parthasarathy M, Annamalai K. An assessment on performance, emission and combustion characteristics of single cylinder diesel engine powered by Cymbopogon flexuosus biofuel. Energy Convers. Manag. 2016 Jun 1;117:466-74.

[29]. Choudhari S, Thenmozhi MS. Occurrence and Importance of Posterior Condylar Foramen. LATERALITY. 2016 Aug 28;8:11-43.

[30]. Paramasivam A, Vijayashree Priyadharsini J, Raghunandhakumar S. N6adenosine methylation (m6A): a promising new molecular target in hypertension and cardiovascular diseases. Hypertens Res. 2020 Feb;43(2):153154.Pubmed PMID: 31578458.

[31]. Wu F, Zhu J, Li G, Wang J, Veeraraghavan VP, Krishna Mohan S, et al. Biologically synthesized green gold nanoparticles from Siberian ginseng induce growth-inhibitory effect on melanoma cells (B16). Artif Cells Nanomed Biotechnol. 2019 Dec;47(1):3297-3305.Pubmed PMID: 31379212.

[32]. Palati S, Ramani P, Shrelin HJ, Sukumaran G, Ramasubramanian A, Don $\mathrm{KR}$, et al . Knowledge, Attitude and practice survey on the perspective of oral lesions and dental health in geriatric patients residing in old age homes. Indian J Dent Res. 2020 Jan-Feb;31(1):22-25.Pubmed PMID: 32246676.

[33]. Saravanan M, Arokiyaraj S, Lakshmi T, Pugazhendhi A. Synthesis of silver nanoparticles from Phenerochaete chrysosporium (MTCC-787) and their antibacterial activity against human pathogenic bacteria. Microb Pathog. 2018 Apr;1 17:68-72.Pubmed PMID: 29427709.

[34]. Govindaraju L, Gurunathan D. Effectiveness of Chewable Tooth Brush in Children-A Prospective Clinical Study. J Clin Diagn Res. 2017 Mar;11(3):ZC31-ZC34.Pubmed PMID: 28511505.

[35]. Vijayakumar Jain S, Muthusekhar MR, Baig MF, Senthilnathan P, Loganathan S, Abdul Wahab PU, et al. Evaluation of Three-Dimensional Changes in Pharyngeal Airway Following Isolated Lefort One Osteotomy for the Correction of Vertical Maxillary Excess: A Prospective Study. J Maxillofac Oral Surg. 2019 Mar;18(1):139-146.Pubmed PMID: 30728705.

[36]. Re Cecconi D, Achilli A, Tarozzi M, Lodi G, Demarosi F, Sardella A, et al. Mucoceles of the oral cavity: a large case series (1994-2008) and a literature review. Med Oral Patol Oral Cir Bucal. 2010 Jul 1;15(4):e551-6.Pubmed PMID: 20038883.

[37]. Christabel A, Anantanarayanan P, Subash P, Soh CL, Ramanathan M, Muthusekhar MR, et al. Comparison of pterygomaxillary dysjunction with tuberosity separation in isolated Le Fort I osteotomies: a prospective, multi-centre, triple-blind, randomized controlled trial. Int J Oral Maxillofac Surg. 2016 Feb;45(2):180-5.Pubmed PMID: 26338075.

[38]. Marimuthu M, Andiappan M, Wahab A, Muthusekhar MR, Balakrishnan A, Shanmugam S. Canonical Wnt pathway gene expression and their clinical correlation in oral squamous cell carcinoma Indian J Dent Res. 2018 May $1 ; 29(3): 291-7$

[39]. Patil SB, Durairaj D, Suresh Kumar G, Karthikeyan D, Pradeep D. Comparison of Extended Nasolabial Flap Versus Buccal Fat Pad Graft in the Surgical Management of Oral Submucous Fibrosis: A Prospective Pilot Study. J Maxillofac Oral Surg. 2017 Sep;16(3):312-321.Pubmed PMID: 28717289.

[40]. Abhinav RP, Selvarasu K, Maheswari GU, Taltia AA. The patterns and etiology of maxillofacial trauma in South India. Ann Maxillofac Surg. 2019 Jan;9(1):114-7.

[41]. Nico MM, Park JH, Lourenço SV. Mucocele in pediatric patients: analysis of 36 children. Pediatr. Dermatol. 2008 May;25(3):308-11.

[42]. liveira DT, Consolaro A, Freitas FJ. Histopathological spectrum of 112 cases of mucocele. Braz Dent J. 1993;4(1):29-36.Pubmed PMID: 8180481.
[43]. Shamim T. Oral mucocele (mucous extravasation cyst). J Ayub Med Coll Abbottabad. 2009;21(1):169.

[44]. Sneha S. Knowledge and awareness regarding antibiotic prophylaxis for infective endocarditis among undergraduate dental students. Asian J. Pharm. Clin. Res. 2016 Oct 1:154-9.

[45]. Kumar S. The emerging role of botulinum toxin in the treatment of orofacial disorders: Literature update. Asian J. Pharm. Clin. Res. 2017;10(9):21-9.

[46]. Sweta VR, Abhinav RP, Ramesh A. Role of Virtual Reality in Pain Perception of Patients Following the Administration of Local Anesthesia. Ann Maxillofac Surg. 2019 Jan-Jun;9(1):110-113.Pubmed PMID: 31293937.

[47]. Jesudasan JS, Wahab PU, Sekhar MR. Effectiveness of $0.2 \%$ chlorhexidine gel and a eugenol-based paste on postoperative alveolar osteitis in patients having third molars extracted: a randomised controlled clinical trial. $\mathrm{Br}$ J Oral Maxillofac Surg. 2015 Nov;53(9):826-30.Pubmed PMID: 26188932.

[48]. Rao TD, Kumar MS. Analgesic efficacy of paracetamol vs ketorolac after dental extractions. Res J Pharm Technol. 2018 Aug 1;11(8):3375-9.

[49]. Rahman R. Knowledge, Attitude And Awareness Of Dental Undergraduate Students Regarding Hiv/Aids Patients. Asian J. Pharm. Clin. Res. 2017 May $1: 175-80$.

[50]. Vijayashree Priyadharsini J. In silico validation of the non-antibiotic drugs acetaminophen and ibuprofen as antibacterial agents against red complex pathogens. J Periodontol. 2019 Dec;90(12):1441-1448.Pubmed PMID: 31257588.

[51]. PC J, Marimuthu T, Devadoss P, Kumar SM. Prevalence and measurement of anterior loop of the mandibular canal using CBCT: A cross sectional study. Clin Implant Dent Relat Res. 2018 Apr 6;20(4):531-4.

[52]. Ramesh A, Varghese S, Jayakumar ND, Malaiappan S. Comparative estimation of sulfiredoxin levels between chronic periodontitis and healthy patients - A case-control study. J Periodontol. 2018 Oct;89(10):1241-1248.Pubmed PMID: 30044495.

[53]. Ramadurai N, Gurunathan D, Samuel AV, Subramanian E, Rodrigues SJ. Effectiveness of $2 \%$ Articaine as an anesthetic agent in children: randomized controlled trial. Clin Oral Investig. 2019 Sep;23(9):3543-50.

[54]. Sridharan G, Ramani P, Patankar S, Vijayaraghavan R. Evaluation of salivary metabolomics in oral leukoplakia and oral squamous cell carcinoma. J Oral Pathol Med. 2019 Apr;48(4):299-306.

[55]. Ezhilarasan D, Apoorva VS, Ashok Vardhan N. Syzygium cumini extract induced reactive oxygen species-mediated apoptosis in human oral squamous carcinoma cells. J Oral Pathol Med. 2019 Feb;48(2):115-121.Pubmed PMID: 30451321.

[56]. Mathew MG, Samuel SR, Soni AJ, Roopa KB. Evaluation of adhesion of Streptococcus mutans, plaque accumulation on zirconia and stainless steel crowns, and surrounding gingival inflammation in primary molars: randomized controlled trial. Clin Oral Investig. 2020 Sep;24(9):1-6.Pubmed PMID: 31955271.

[57]. Samuel SR. Can 5-year-olds sensibly self-report the impact of developmental enamel defects on their quality of life? Int J Paediatr Dent. 2021 Mar;31(2):285-286.Pubmed PMID: 32416620.

[58]. R H, Ramani P, Ramanathan A, R JM, S G, Ramasubramanian A, et al. CYP2 C9 polymorphism among patients with oral squamous cell carcinoma and its role in altering the metabolism of benzo[a]pyrene. Oral Surg Oral Med Oral Pathol Oral Radiol. 2020 Sep;130(3):306-312.Pubmed PMID: 32773350 .

[59]. Chandrasekar R, Chandrasekhar S, Sundari KKS, Ravi P. Development and validation of a formula for objective assessment of cervical vertebral bone age. Prog Orthod. 2020 Oct 12;21(1):38.Pubmed PMID: 33043408.

[60]. Vijayashree Priyadharsini J, Smiline Girija AS, Paramasivam A. In silico analysis of virulence genes in an emerging dental pathogen A. baumannii and related species. Arch Oral Biol. 2018 Oct;94:93-98.Pubmed PMID: 30015217. 